\title{
The modernization of public spaces in problematic residential areas exemplified on selected projects and realizations in the Bronowice district of Lublin
}

\author{
Kamila Boguszewska \\ e-mail: k.boguszewska@pollub.pl \\ Natalia Przesmycka \\ e-mail: n.przesmycka@pollub.pl \\ Department of Architecture and Urban Planning, \\ Faculty of Civil Engineering and Architecture
}

\begin{abstract}
Summary: Tatary and Bronowice are considered to be the most dangerous and problematic districts of Lublin. The problems are exacerbated by the changing age structure of the residents - "ageing" and a high percentage of the unemployed, caused by the collapse of industry in Lublin after 1989 (URSUS), which was the main sector of employment for the residents of these districts. Apart from the problems typical for all housing estates from the communist era, e.g. lack of parking spaces, there is vandalism, alcoholism and low material status of the residents.

The development of the Tatary district after World War II was connected with the industrial district (among industrial plants, the biggest employer was the Fabryka Samochodów Ciężarowych (Heavy Goods Vehicle Factory) established in 1951, there was a slaughterhouse, and now - meat processing plants.

Housing estates built within the Tatary district in 1950-1972 (ZOR Tatary and Motor) and Bronowice (ZOR Bronowice | 1954-1956 and Bronowice II and III 1956-1969) were characterised by a large share of green and recreational areas dedicated to various users. After several decades of lack of investment and with changing lifestyles and users' needs, these spaces are among the most neglected in Lublin. Currently works related to the improvement of infrastructure in these housing estates are being undertaken such as: replacement of street lights, sidewalks, etc. District councils are working intensively to raise funds for the most urgent needs, but they are not always well thought out or designed in an appropriate way. The problem is the lack of models and often duplication of functional and aesthetic schemes, not always appropriate to the area.

The modernization of public spaces is one of the elements of revitalisation processes, in which the involvement of future users at the design stage is a necessary element. Good public spaces increase the sense of security, comfort of living and even contribute to the increase in real estate prices. This paper presents the problems posed by the design process, implementation and functioning of selected public spaces in Tatary and Bronowice districts of Lublin where community participation played a crucial role.

The article presents issues related to the design, implementation and functioning of selected public spaces in the Bronowice district, where social participation was an important factor. Challenges of public space modernization in problematic residential areas are exemplified on selected projects and realizations in the Bronowice district of the city of Lublin.
\end{abstract}

Keywords: Bronowice district of Lublin, public spaces modernization, housing estates in Lublin

\section{Introduction}

The Bronowice district of Lublin is composed of several different kinds of housing developments. This is caused by the historic development of the area. The oldest part of Bronowice - Stare Bronowice is localized along the 
banks of the Bystrzyca river and the railway line and spans in north-eastern direction. Second half of the XIX century saw the development of housing related to the strong growth of industrial manufacturing in the area. This period of growth lasted for several decades until first half of the XX century. ${ }^{1}$ During the interwar period many industrial plants were localized in the area, biggest of which was the airplane factory. The main public space at the time was the City Garden of Foksal, established in 1869 the Garden is still functioning today. After the war the industrial area had kept its role to some point with Lublin Auto Repair Facility being located there by the authorities ${ }^{2}$. The area of the airstrip had been used for the construction of new housing estates. The post-war estates are separated from the pre-war housing by the industrial area.

The post war housing estates of the Bronowice district (ZOR Bronowice I 1954-1956, Bronowice II and III 1956-1969 and the Maki (Poppy) estates) were characterized by a big share of green recreation areas dedicated for various uses.

The Workers' Housing Development Administration (Zakład Osiedli Robotniczych, ZOR) operated during the 1949-1955 period. The estates being constructed as part of the ZOR effort realized the housing program accompanying the development of new plants and other industrial facilities in the south-eastern part of Lublin. The implementations from that period display exemplary characteristics of the social realism trend in architecture of the city of Lublin.

In the early period of ZOR their developments continued with the traditional city street model with city blocks with services and facility spaces located on the ground floors of new buildings. M. Kurzątkowski remarks on the subject: spatial planning had not immediately broke with the old peripheral estate model. ${ }^{3}$ ZOR estates had bomb shelters built which are now under the management of Security and crisis management department of the city of Lublin town hall.

When Wladyslaw Gomułka became Ist Secretary of the Polish United Workers' Party (1956) the task of housing estates construction was handed over to cooperative building societies modeled after similar prewar organizations. The Council of Ministers had moved the ZOR housing to local National Councils. ${ }^{4}$ Estates being constructed during that period no longer bear the characteristics of the old pre-war peripheral quarter model. Instead the new implementations are completely fitted urban units. The buildings designed in that era are 5 floor stairwell buildings and 8-10 floor high risers. ${ }^{5}$ Service premises are moved from the ground floors of newly designed building to separate buildings and pavilions. The majority of estate construction technology is industrialized.

The Bronowice district has been gradually growing in the following years absorbing suburban gardens orchards and small farms expanding east (Pogodna and Krańcowa Streets). The paper will describe examples of relicts left behind by former spatial arrangement. ... Works improving the infrastructure are constantly being carried out however some glaring omissions, especially in the "inter-block" space of the ZOR developments are obvious. ZOR estates are sticking out like a sore thumb against the remaining estates of Bronowice.

\section{Social participation in the investement decision making process vs social issues}

Social evaluation of Bronowice district's area puts parts of the Stare (old) Bronowice and the ZOR estates among the least friendly and most dangerous districts in the city of Lublin. The introduction of free market economy

1 The residential district, consisting mainly of two or three storey tenement houses, stretched between the railway line and grassland by the Bystrzyca River. Łęczyńska Street leading to the village of Tatary was its main communication axis. Bronowicka Street (originally leading to the municipal slaughterhouse) was designed parallel to Łęczyńska Street. Between them a system of parallel streets was laid out, in time filled with workers' houses. N. Przesmycka, Lublin. Urban transformations 1815-1939, Lublin 2012, p. 109. After several decades of lack of investment, in view of the changing lifestyle and users' needs, these spaces are among the most neglected in Lublin. The condition of the so-called Old Bronowice became so bad in terms of both technical and social degradation that this area is covered at the moment by the City's Revitalisation Programme. The article focuses on initiatives and actions undertaken in the remaining part of the housing estate.

2 Studziński J., Zakłady mechaniczne E. Plage i T. Laśkiewicz, [w:] Czerepińska J., Michalska G., Studziński J., Katalog architektury przemysłowej w Lublinie, t. I, cz. I, s. 68.

3 Kurzątkowski M., Lublin trzech pokoleń, s. 11

4 Kurier Lubelski, 7-8 IV, 1957, R 1, nr 13.

5 Budownictwo i Architektura w Polsce 1945-1966, Praca Zbiorowa pod red. Prof. Dr J. Zachwatowicza, Wyd. Interpress Warszawa 1968, S. 43 
in the beginning of 1990s led to the creation of real estate market however the majority of apartments in Bronowice remained in the ownership of their first tenants. As is the case in the ZOR estates - the majority of tenants are older people in retirement. Until this day the prices of apartments and rents are among the lowest in Lublin. Bronowice district exemplifies a country wide tendency for such estates to become drained of young people. Young aspiring people are seeking out different districts with new modern estate buildings.

Covering the Stare Bronowice with the revitalisation program is a chance to transform this part of the district completely. Unfortunately the part of the Bronowice described in this paper is not under the program since the unfavourable social phenomena gauge is slightly below the required level. ${ }^{6}$ However the overall image of the district as "problematic" is due to the disproportions in the state of social technical and economic space in the district.

Modernising of the public space is essential to the revitalisation process it is of utmost importance to engage the future users already on the level of design. Good well designed public spaces are a part of elevated feeling of security, dwelling comfort and are also contributing to the growing real estate prices. Civic participation, expressed in the recent years by growing interest in the quality of surrounding space is in turn shaping the city spatial policy. ${ }^{7}$ Unfortunately the decisions made by residents are not necessarily thought through. The main issue as presented in this paper is the lack of norms and standards which leads to duplication of previous implementations, rarely adequate for the new application.

\section{District Council's initiative}

The council moved to rectify the attractiveness of the estate to its residents as an important element of improving the feeling of self worth and to strengthen the attachment to their place of residence. Since they were erected the buildings of Bronowice with their surrounding spaces were neglected, underinvested and dilapidated especially in the oldest part (ZOR estates) which led to the growing divide into "better" and "worse" Bronowice.

Back in 2010 the district council have moved forward with the initiative to improve the quality of its public space. The main idea revolved around the development of four new squares named after saints and important figures in the Catholic Church: St. John Paul II, Blessed George Popiełuszko, Cardinal Stefan Wyszyński and Our Lady of Fatima.

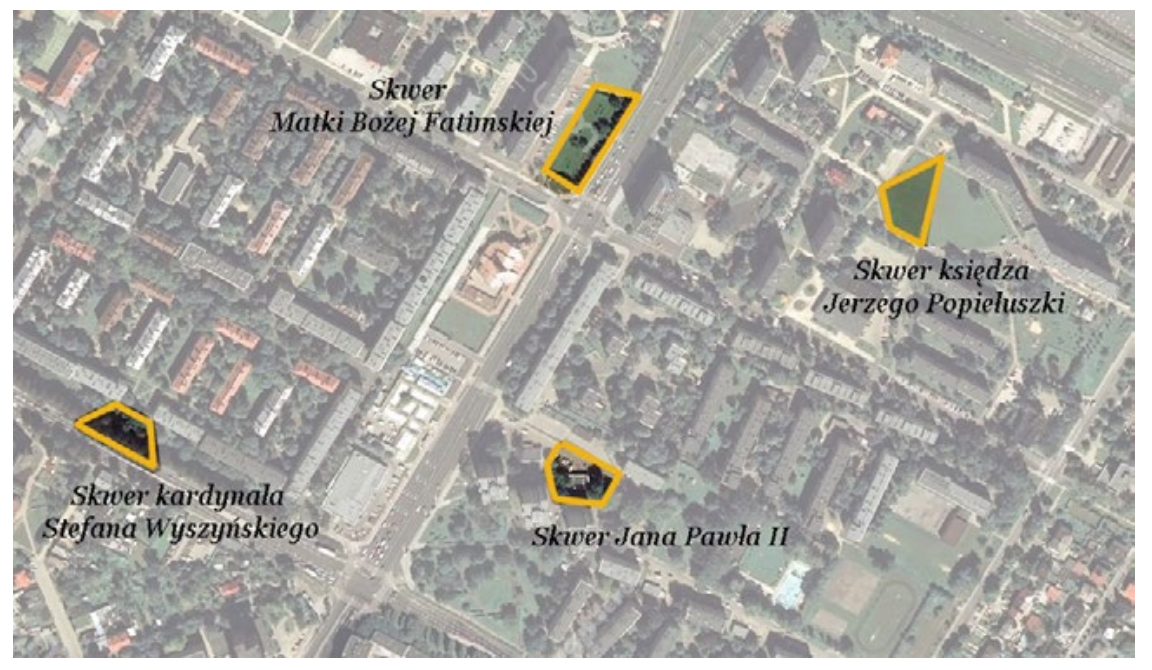

Fig. 1. Placement of squares in the space of the Bronowice estate. On the left side of the ZOR estate. Compiled by the author

The residents intended the squares to take the form of organized, fenced places of worship in the form of exhibited sculptures - figural representations. The inhabitants wanted to enliven the space by introducing 
decorative plantings of low shrubs and perennials. Concepts, followed by construction and detailed designs, were realized by KAUiPP employees on behalf of the Lublin Environmental Protection Foundation, and from the very beginning they were subject to social consultations. In order to improve communication, not only visualizations of places, but also mock-ups, which were presented during a series of meetings, were made for the need to present project ideas. Public consultations were a tool for developing a design solution acceptable to the widest possible group of recipients, meeting contemporary aesthetic and functional standards. The lack of budgetary restrictions (caused by the initial lack of an idea for financing the project) gave the designers the opportunity to choose high-quality material and technical solutions, and to design individual elements of small architecture objects. The four locations indicated by the district council included spaces with different levels of investment and use to date (Fig. 1).

According to the residents, the figures of saints and fences were supposed to prevent devastation of the space and contribute to increasing the level of safety, especially in part of the ZOR housing estate. The indicated locations differed in terms of relation to the existing buildings, the scale of the interior, the existing elements of development, vegetation, etc. The residents' initiative to introduce forms of spatial devastation and to contribute to the improvement of safety, especially in part of the ZOR housing estate. The initiative of the inhabitants to introduce sculptural forms with religious content required a wide discussion - there was a threat of appropriation of public space and, above all, the questionable quality of monument construction. The main idea of the developed project resulted from the desire to show the residents that it is possible to approach the issue of worshiping selected patrons differently, without image, basing only on the most important and universal messages carried by them. The idea - a monument of thought - an element common to all squares in the form of a new individual form in the landscape of the housing estate was accepted after public consultations. The common form for various architectural elements, during the participatory process underwent gradual transformations, presented below. The idea of a concrete element with inscriptions in the form of concave reliefs was accepted by the inhabitants. The choice of sentences placed on them was widely consulted. As a result, an element visually identifying the designed spaces was obtained, unique and individual, which, depending on the location, could be a free-standing obelisk, a lantern, a pillar of pergola or a fence (Fig. 2.).

A
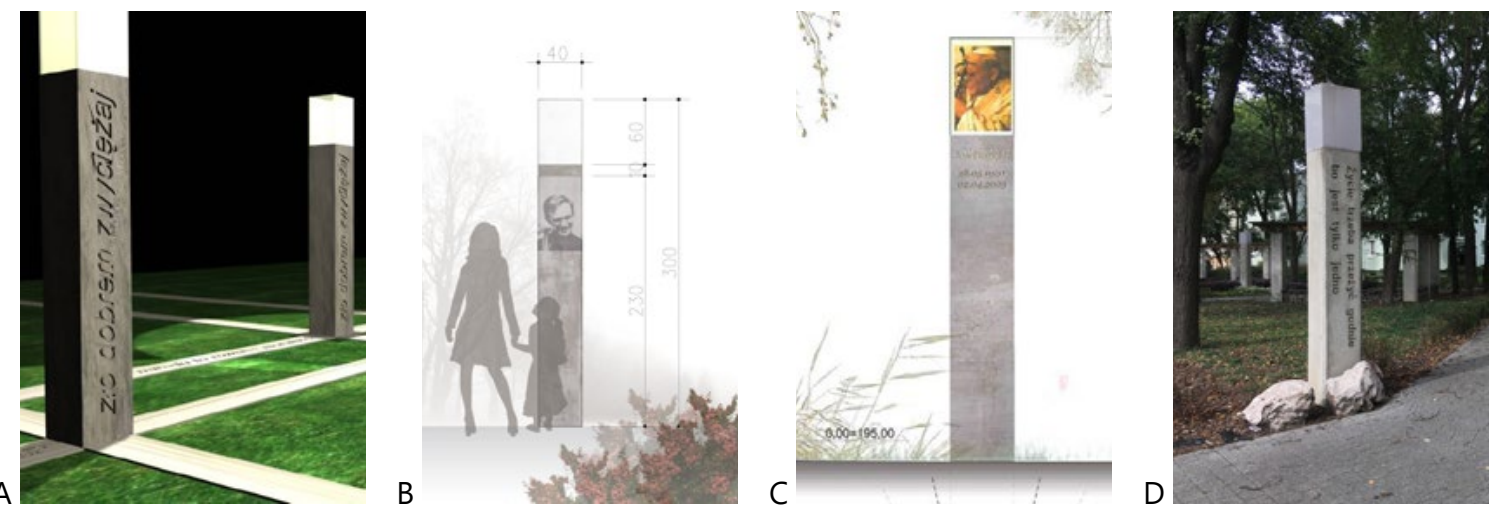

Fig. 2. A - the first initial concept presented during social participation, B, C - "image" concepts presented during social participation, D - implementation - the original concept. Compiled by the author

Table 1. Summary of issues related to the discussed public spaces in the Bronowice district.

\begin{tabular}{|ccccc|}
\hline & $\begin{array}{c}\text { Cardinal Stefan } \\
\text { Wyszyński Square }\end{array}$ & $\begin{array}{c}\text { Father Jerzy } \\
\text { Popieluszko's } \\
\text { Square }\end{array}$ & $\begin{array}{c}\text { St. John Paul II } \\
\text { Square }\end{array}$ & $\begin{array}{c}\text { Our Lady of } \\
\text { Fatima Square }\end{array}$ \\
$\begin{array}{c}\text { Duration of the } \\
\text { participatory } \\
\text { process }\end{array}$ & $06-12.2010$ & $06-12.2010$ & $06-12.2010$ & $06-12.2010$ \\
\hline $\begin{array}{c}\text { Year of project } \\
\text { implementation }\end{array}$ & June 2010 & June 2010 & June 2010 & June 2010 \\
\hline
\end{tabular}




\begin{tabular}{|c|c|c|c|c|}
\hline $\begin{array}{c}\text { Year of } \\
\text { construction } \\
\text { (commissioning) }\end{array}$ & 2013 & 2012 & 2012 & - \\
\hline $\begin{array}{c}\text { Area before } \\
\text { starting design } \\
\text { works }\end{array}$ & $\begin{array}{l}\text { The communication } \\
\text { route between the } \\
\text { estate, bus stop and } \\
\text { church. }\end{array}$ & $\begin{array}{l}\text { The communication } \\
\text { route - trodden } \\
\text { path }\end{array}$ & $\begin{array}{l}\text { The zone next to } \\
\text { the "Nie Lękajcie } \\
\text { się" youth centre } \\
\text { - a very technically } \\
\text { degraded area }\end{array}$ & $\begin{array}{l}\text { Former orchard } \\
\text { area, dog } \\
\text { walking area, } \\
\text { viewing link to } \\
\text { the church }\end{array}$ \\
\hline $\begin{array}{l}\text { The wishes of } \\
\text { the residents }\end{array}$ & \multicolumn{4}{|c|}{ The sculpture of the patron saint of the square or a chapel, "flowery". } \\
\hline $\begin{array}{c}\text { Designers' } \\
\text { proposal }\end{array}$ & \multicolumn{4}{|c|}{$\begin{array}{l}\text { Lack of images, unaccompanied message in a universal form on the elements of small } \\
\text { architecture, Plants symbolism or colour relating to the patron of the square. }\end{array}$} \\
\hline $\begin{array}{l}\text { Working } \\
\text { solution }\end{array}$ & $\begin{array}{l}\text { A centrally located } \\
\text { illuminated obelisk with } \\
\text { reliefs and reliefs on } \\
\text { pergola and lighting } \\
\text { poles. Application of } \\
\text { planting in violet, purple } \\
\text { (lat. Clematis ,Kardynał } \\
\text { Wyszyński'), and white } \\
\text { and red seasonal } \\
\text { flowers. }\end{array}$ & $\begin{array}{l}\text { Reliefs on the } \\
\text { pergola and } \\
\text { lighting poles, free- } \\
\text { standing obelisks. } \\
\text { Application of } \\
\text { plantings with } \\
\text { dominant violet } \\
\text { colour. Reliefs } \\
\text { on fence pillars, } \\
\text { pergola included in } \\
\text { the fence line. }\end{array}$ & $\begin{array}{l}\text { Reliefs on the } \\
\text { fence posts } \\
\text { pergola } \\
\text { incorporated into } \\
\text { the fence. } \\
\text { Planting blooming } \\
\text { or coloring white } \\
\text { and yellow. }\end{array}$ & $\begin{array}{l}\text { Reliefs on the } \\
\text { pergola and } \\
\text { lighting poles } \\
\text { Selection of } \\
\text { plants of Marian } \\
\text { symbolism } \\
\text { (e.g. roses, } \\
\text { perennials) and } \\
\text { the preservations } \\
\text { of orchard. }\end{array}$ \\
\hline $\begin{array}{l}\text { The wishes of } \\
\text { the residents }\end{array}$ & \multicolumn{4}{|c|}{ Fencing of squares, locking gates. } \\
\hline $\begin{array}{c}\text { Designers' } \\
\text { proposal }\end{array}$ & \multicolumn{4}{|c|}{ Lack of fencing } \\
\hline $\begin{array}{l}\text { Working } \\
\text { solution }\end{array}$ & $\begin{array}{l}\text { Medium-high hedges } \\
\text { (Berberys) }\end{array}$ & $\begin{array}{l}\text { Low hedge, } \\
\text { decorative }\end{array}$ & Locking gates. & - \\
\hline $\begin{array}{l}\text { The wishes of } \\
\text { the residents }\end{array}$ & \multicolumn{4}{|c|}{ Square function: a place of adoration, worship, contemplation } \\
\hline $\begin{array}{c}\text { Designers' } \\
\text { proposal }\end{array}$ & $\begin{array}{l}\text { Meeting place for } \\
\text { different social groups }\end{array}$ & $\begin{array}{l}\text { A place of } \\
\text { recreation for } \\
\text { various social } \\
\text { groups }\end{array}$ & $\begin{array}{l}\text { Opening of the } \\
\text { Centre's area } \\
\text { for residents, } \\
\text { integration with } \\
\text { the housing estate }\end{array}$ & $\begin{array}{l}\text { Meeting place } \\
\text { for different } \\
\text { social groups }\end{array}$ \\
\hline $\begin{array}{l}\text { Working } \\
\text { solution }\end{array}$ & $\begin{array}{c}\text { Resting place for varoius } \\
\text { social groups, benches } \\
\text { by the communication } \\
\text { routes }\end{array}$ & $\begin{array}{c}\text { A resting place } \\
\text { for different social } \\
\text { groups }\end{array}$ & $\begin{array}{c}\text { Development of } \\
\text { the area near the } \\
\text { Centre }\end{array}$ & $\begin{array}{c}\text { Place of } \\
\text { contemplation, } \\
\text { walking }\end{array}$ \\
\hline
\end{tabular}

\section{Cardinal Stefan Wyszyński Square}

Cardinal Stefan Wyszyński Square was located on the entrance axis of the pedestrian route connecting the oldest part of the ZOR Bronowice estate with the church. The simple geometric form fits into the existing system of communication routes, creating a space equipped with benches and pergolas. The central element of the system is a single post-lighthouse with inscriptions on each wall. Special attention has been paid to the selection of species of the designed plants. Efforts were made to ensure that the species or colours had a reference to Christian symbolism. In the Cardinal Stefan Wyszyński Square, seasonal white and red flowers were also designed, emphasizing the patriotic character of the place. 


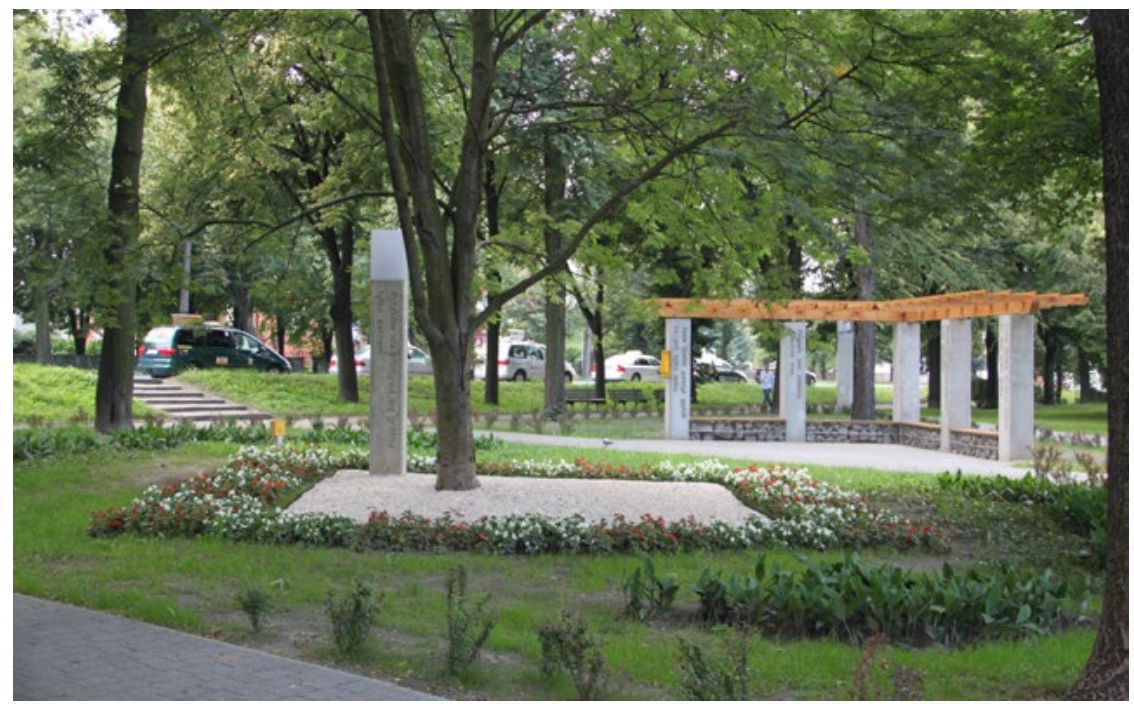

Fig. 3. A fragment of Cardinal Stefan Wyszyński's Square, photograph by author, 2016.

\section{St. John Paul II Square}

St. John Paul II Square is located on the grounds of the "Nie Lękajcie Się" Youth Centre. The design challenge was to bring together the recreational with utilitarian functions i.e. parking spaces for employees, waste disposal site and the requirement of having the area fenced which previously was open to public. The design retained the pre-existing communication infrastructure comprised of sidewalks and paths with gates localized along the walking routes.
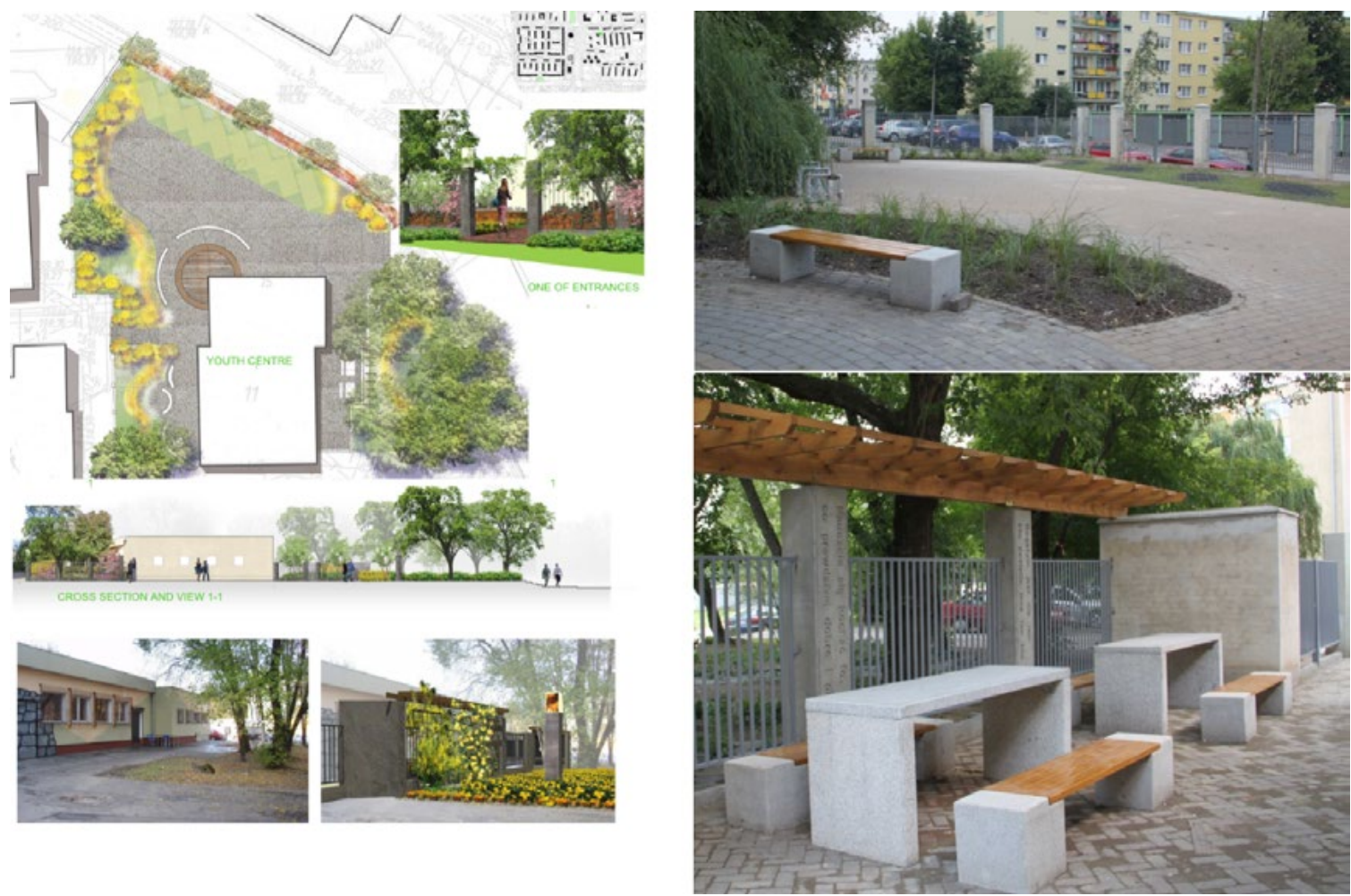

Fig. 4. Excerpt from the project documentation and its implementation, photograph by author, 2016. 
The poles identifying the space, common to all the discussed spaces, are incorporated into the layout of the fence. The existing clinker brick floor surface has been preserved in this area, which has been reconstructed and reused. The most important space is the eastern part of the installation with seating places and benches located inside the square, and from the outside with a single obelisk with intentions in the form of reliefs.

The choice of plants was based on its symbolism related to the figure of the Pope. The species chosen were yellow or white blooming, planted with grasses turning their colours during autumn and winter and birch trees along the fence.

\section{Father Jerzy Popiełuszko Square}

The square was designed inside a housing estate in an open, non-built non-utilised area, which so far has served as a pedestrian communication route. The main axes of this communication determined the course of the designed paths. The character of the square was supposed to be foster passive recreation and contemplation; hence the pergolas with benches were used as main elements of the composition. The square was to remain an open space without tall trees, at the same time creating places to rest in the shade (pergolas). The plants were to refer to the martyrdom of the patron, so the species were chosen with the dominant violet colour: heathers, sage, ornamental garlic, decorative grasses, and burgundy-coloured: barberries and five lobed vines. It was the first project in Lublin with the use of such a large number of perennials in the housing estate public space.

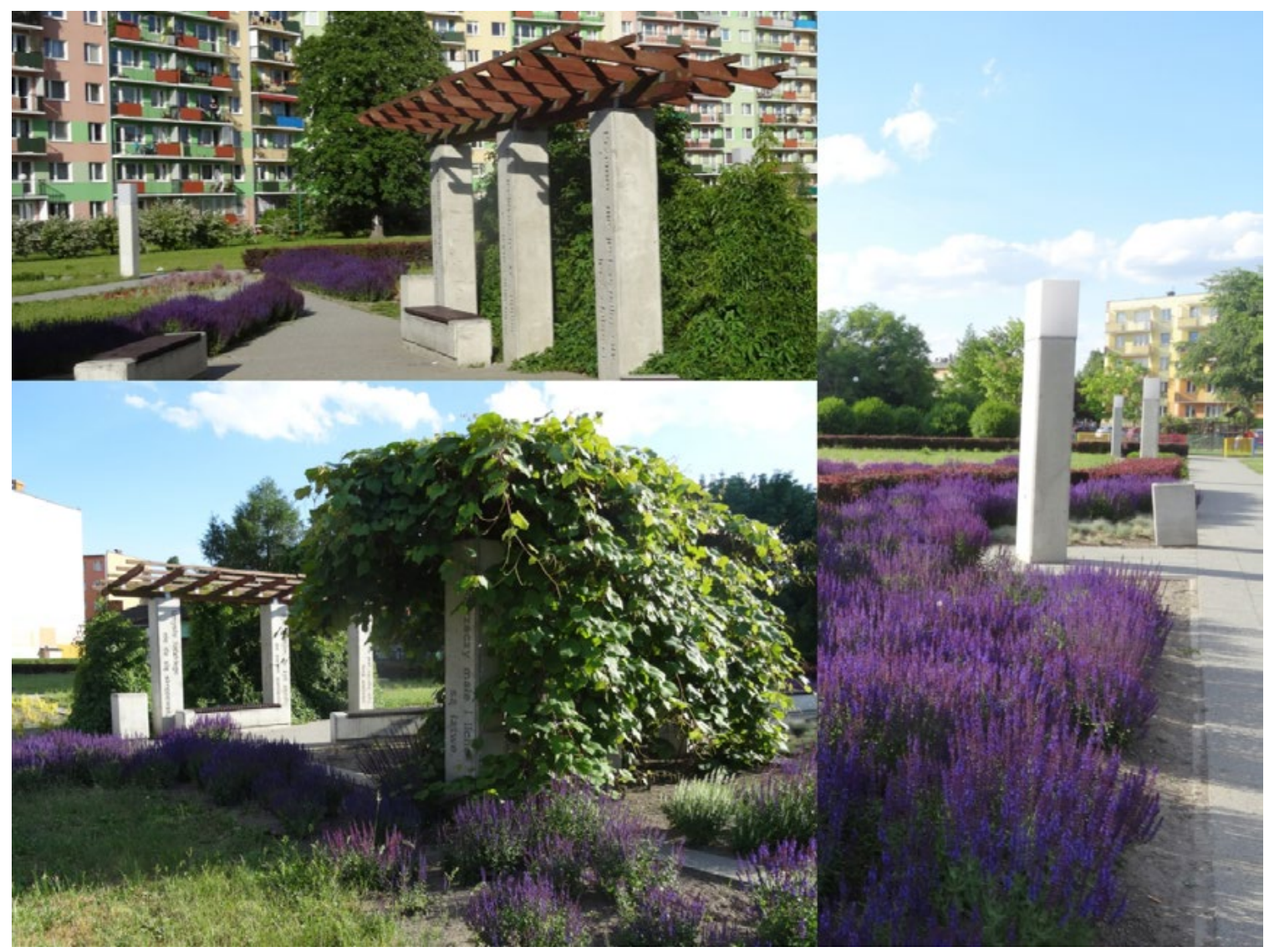

Fig. 5. Father Jerzy Popiełuszko Square pergolas with inscriptions, photograph by author, 2016. 


\section{Our Lady of Fatima Square}

The square was designed on the area of a former orchard adjacent to a busy street. The main concept involved preserving all existing trees including them in the composition. The designed path with an unsealed surface has a winding, geometric shape, creating garden interiors in six zones. Each of those has a different character thanks to the use of plants of Marian symbolism or referring to Marian holidays. Subsequent zones are: May Corner (lilies, lilies of the valley, and bellflowers), summer Corner (mallows, cereals and poppies), herb garden (mint, sage, lavender, thyme, stock), blooming meadow (flower meadow), white garden and fragrant flower garden. The choice of species guaranteed the year-round attractiveness of the place. The obelisks, located in the centre of each zone, have reliefs of sentences containing universal messages from the Fatima apparitions engraved.

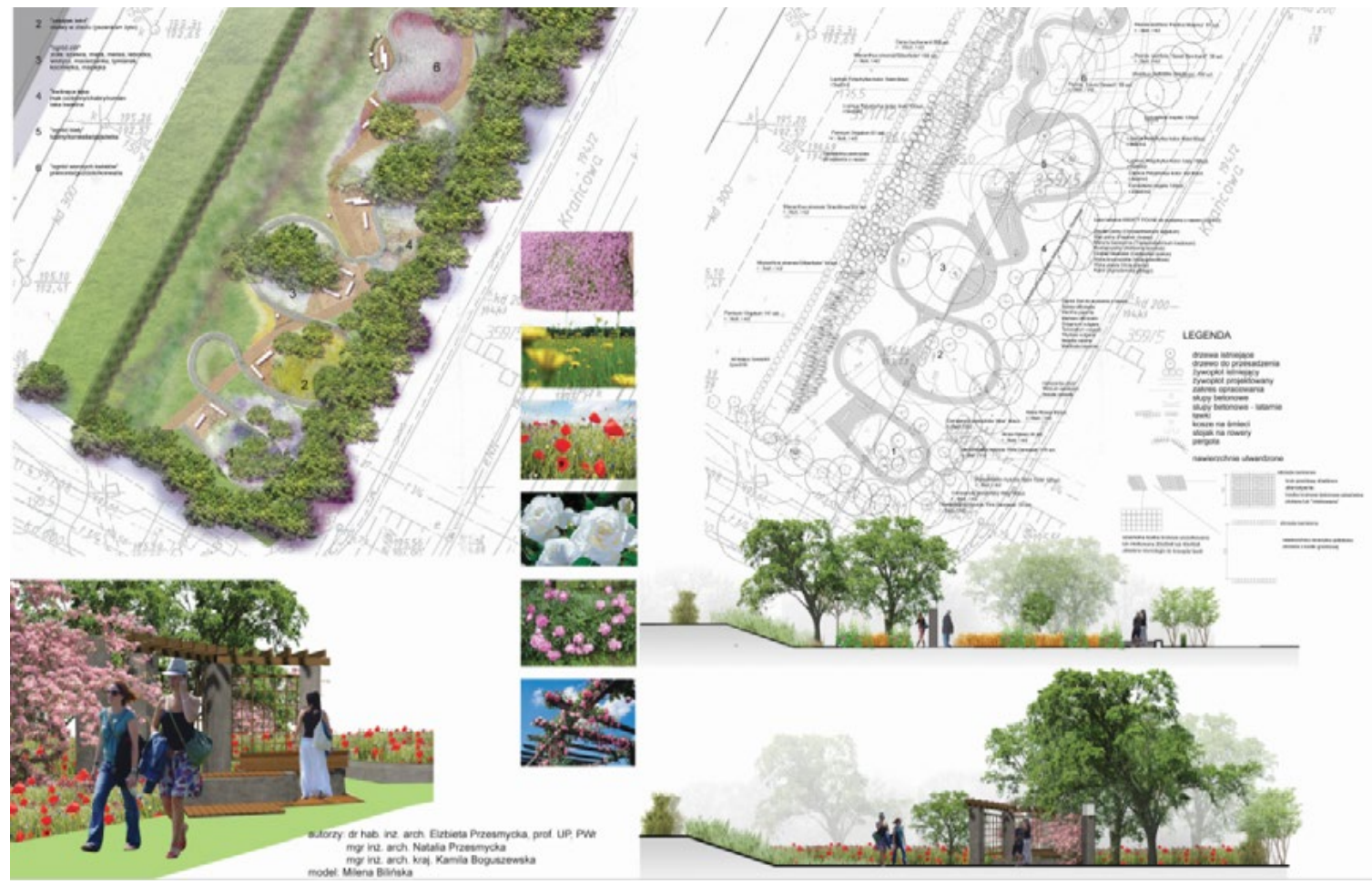

Fig. 6. Excerpts from the project conceptual and construction documentation

\section{Summary}

Three of the four squares described above have been completed. The realization of the square of Our Lady of Fatima is the subject of constant efforts on behalf of the district council to secure funding. After several years of operation, one can see varying degrees of upkeep and maintenance. What is interesting, the most neglected is the area near the "Nie Lękajcie Się" Youth Centre, which confirms the designers' reluctance towards public premises dedicated to a single group of end users with additional fencing surrounding the designed area. The Cardinal Stefan Wyszyński Square, located in a prominent location on Męczenników Majdanka Street, is cared for most. Seasonal plants forming a white and red background for the obelisk are replaced twice a year. The implementation of this square was the beginning of further construction and gardening works aimed at improving the aesthetics of this part of the street. On Father Jerzy Popiełuszko Square, due to insufficient plant care, after two years the planting was partially changed to bushes (barberries and meadowsweets) were introduced since they do not require much maintenance. There was no devastation or acts of vandalism in any of the squares. The spaces have merged into the neighbourhood landscape, have increased the attractiveness of public spaces and are an example of successful public participation at the pre-design and design stages of a project. 


\title{
References
}

[1] Budownictwo i Architektura w Polsce 1945-1966, Praca Zbiorowa pod red. Prof. Dr J. Zachwatowicza, Wyd. Interpress Warszawa 1968, s. 43.

[2] Kot N., Zieleń lubelskich Bronowic - tradycja miejsca w kontekście współczesnych przekształceń, Architectus 2017 3 (51), s. 65-77

[3] Kurier Lubelski, 7-8 IV, 1957, R 1, nr 13.

[4] Kurzątkowski M., Lublin trzech pokoleń, s. 11

[5] N. Przesmycka, Lublin. Przeobrażania Urbanistyczne 1815-1939, Lublin 2012,

[6] Studziński J., Zakłady mechaniczne E. Plage i T. Laśkiewicz, w: Czerepińska J., Michalska G., Studziński J., Katalog architektury przemysłowej w Lublinie, t. I, cz. I, s. 68.

[7] Uchwała nr 735/XXIX/2017 Rady Miasta Lublin z dnia 27 kwietnia 2017 r.

[8] Studziński J., Zakłady mechaniczne E. Plage i T. Laśkiewicz, [w:] Czerepińska J., Michalska G., Studziński J., Katalog architektury przemysłowej w Lublinie, t. I, cz. I, s. 68.

[9] Projekty budowlane skwerów ks. Jerzego Popiełuszki, Matki Boskiej Fatimskiej, Kardynała St. Wyszyńskiego, Jana Pawła II. Zespół autorski: dr hab. inż. arch. Elżbieta Przesmycka, dr inż. arch. Natalia Przesmycka, mgr inż. arch. kraj. Kamila Boguszewska, mgr inż. arch. Edward Koziołek, Lublin 2010

\section{Modernizacja przestrzeni publicznych w problematycznych dzielnicach mieszkaniowych na przykładzie wybranych projektów i realizacji w dzielnicy Bronowice w Lublinie}

\begin{abstract}
Streszczenie: Tatary i Bronowice uchodzą za najbardziej niebezpieczne i problematyczne dzielnice Lublina. Problemy pogłębia zmieniająca się struktura wiekowa mieszkańców osiedla - "starzenie się", oraz duży odsetek osób niepracujących, spowodowany upadkiem przemysłu w Lublinie po 1989 roku (URSUS), który był głównym sektorem zatrudnienia dla mieszkańców tych dzielnic. Oprócz problemów typowych dla wszystkich osiedli z epoki PRL np. braku miejsc parkingowych, dochodzi wandalizm, alkoholizm i niski status materialny mieszkańców.

Rozwój dzielnicy Tatary po II wojnie światowej wiązał się z dzielnicą przemysłową (wśród zakładów przemysłowych największym pracodawcą była powstała w 1951 roku Fabryka Samochodów Ciężarowych, funkcjonowała rzeźnia, obecnie - zakłady mięsne.

Osiedla powstające w ramach dzielnicy Tatary w latach 1950-1972 (ZOR Tatary oraz Motor) i Bronowic (ZOR Bronowice | 1954-1956 i Bronowice II i III 1956-1969), cechował duży udział terenów zielonych i stref rekreacyjnych dedykowanych różnym użytkownikom. Po kilkudziesięciu latach braku inwestowania i przy zmieniającym się stylu życia oraz potrzebach użytkowników, przestrzenie te należą do najbardziej zaniedbanych w Lublinie. Na bieżąco podejmowane są prace związane z poprawą infrastruktury na osiedlach: wymiana oświetlenia, chodników itd. Rady dzielnic intensywnie pracują nad pozyskiwaniem środków na realizacje najbardziej palących potrzeb, jednak nie zawsze są one przemyślane i zaprojektowane w odpowiedni sposób. Problemem jest brak wzorców i powielanie schematów funkcjonalnych i estetycznych, nie zawsze adekwatnych do danego miejsca.

Modernizacja przestrzeni publicznych jest jednym z elementów procesów rewitalizacyjnych, w których zaangażowanie przyszłych użytkowników jest elementem koniecznym już na etapie projektu. Dobre przestrzenie publiczne podnoszą poczucie bezpieczeństwa, komfortu zamieszkania, a nawet przyczyniają się do wzrostu cen nieruchomości. Artykuł przedstawia problematykę związaną z projektowaniem, realizacją i funkcjonowaniem wybranych przestrzeni publicznych na Tatarach i Bronowicach, w których ważnym elementem była partycypacja społeczna. Artykuł przedstawia problematykę związaną z projektowaniem, realizacją i funkcjonowaniem wybranych przestrzeni publicznych na Bronowicach, w których ważnym elementem była partycypacja społeczna.
\end{abstract}

Słowa kluczowe: Bronowice, rewitalizacja przestrzeni publicznych, osiedla Lublina 